\title{
Gelar Teknologi Pengolahan Kotoran Sapi dan Limbah Rumah Tangga Menjadi Ekscat untuk Meningkatkan Pendapatan Masyarakat
}

\section{${ }^{1}$ Mashur, ${ }^{2}$ Alfiana Laili Dwi Agustin, ${ }^{3}$ Novarina Sulsia Ista'in Ningtyas, ${ }^{4}$ Ahamad Multazam, ${ }^{5}$ Murtiana Ningsih}

${ }^{1,2,3}$ Prodi Pendidikan Kedokteran Hewan, FKH, Undikma Mataram, Jl. Pemuda 59 A, Mataram, Indonesia 83125

${ }^{4}$ Prodi Teknik Sipil, FSTT, Undikma Mataram, Jl. Pemuda 59 A, Mataram, Indonesia 83125

${ }^{5}$ Prodi Kesehatan Masyarakat, FIKKM, Undikma Mataram, Jl. Pemuda 59 A, Mataram, Indonesia 83125

\section{Email Korespondensi: mashurntb40@gamil.com}

\begin{tabular}{|c|c|}
\hline Article Info & Abstract \\
\hline $\begin{array}{l}\text { Article History } \\
\text { Received: } 2020-09-22 \\
\text { Revised: } 2020-10-05 \\
\text { Published: } 2020-10-24\end{array}$ & \multirow[b]{2}{*}{$\begin{array}{l}\text { Degree of Cow Manure and Household Waste Processing Technology into } \\
\text { Exmecat to Increase Community Income. The potential for cow feces and } \\
\text { household organic waste can cause negative impacts in the form of } \\
\text { environmental pollution and public health problems, if not optimally utilized. } \\
\text { The show case technology for treating cow feces and household organic waste } \\
\text { with the Lumbricus rubellus earthworm reactor can produce eksmecat as } \\
\text { organic solid organic fertilizer, increase community income and at the same } \\
\text { time be a solution to solving problems in handling organic waste. This study } \\
\text { aims to determine the ability of earthworms to process cow feces and } \\
\text { household waste into eksmecat and to determine the income of the community } \\
\text { from the resulting eksmecat. The method used in disseminating this technology } \\
\text { is a show case technology. The show case technology is carried out by three } \\
\text { cooperators. The results showed that the earthworm Lumbricus rubellus was } \\
\text { able to process cow feces and organic waste into an extract of } 2,436 \text { times } \\
\text { body weight per day. The resulting eksmecat an average of } 2.463 \text { kg/nest box } \\
\text { with an earthworm stocking density of } 25 \text { g/nest box and cultivation time of } 40 \\
\text { days. Through the application of this technology title, the earthworm cultivator } \\
\text { community with a three-tiered rack system can get an additional income of Rp. } \\
2.008 .712,-/ \text { month / area of cultivation land. The conclusion is that the } \\
\text { processing of cow feces and household waste into eksmecat can be done using } \\
\text { an earthworm reactor with a tiered rack system and can increase people's } \\
\text { income. }\end{array}$} \\
\hline $\begin{array}{l}\text { Keywords } \\
\text { Eksmecat, } \\
\text { technology degree, } \\
\text { cow dung, } \\
\text { Lumbricus rubellus }\end{array}$ & \\
\hline Informas & ADstrak \\
\hline $\begin{array}{l}\text { Sejarah Artikel } \\
\text { Diterima: } 22-09-2020 \\
\text { Direvisi: 05-10-2020 } \\
\text { Dipublikasi: } 24-10-2020\end{array}$ & \multirow{2}{*}{$\begin{array}{l}\text { Potensi kotoran sapi dan limbah organik rumah tangga yang sangat besar } \\
\text { apabila tidak dimanfaatkan secara optimal dapat menimbulkan dampak negatif } \\
\text { berupa pencemaran lingkungan dan gangguan kesehatan masyarakat. Gelar } \\
\text { teknologi pengolahan kotoran sapi dan limbah organik rumah tangga dengan } \\
\text { reaktor cacing tanah Lumbricus rubellus dapat mengasilkan pupuk organik } \\
\text { padat eksmecat, meningkatkan pendapatan masyarakat dan sekaligus menjadi } \\
\text { solusi untuk mengatasi masalah penanganan limbah organik. Kegiatan } \\
\text { pengabdian ini bertujuan untuk memperkenalkan penerapan teknologi } \\
\text { pengolahan kotoran sapi dan limbah rumah tangga menjadi eksmecat kepada } \\
\text { masyarakat dalam rangka meningkatkan pendapatannya. Metode yang } \\
\text { digunakan dalam mendiseminasikan teknologi ini adalah gelar teknologi (show } \\
\text { case technology). Gelar teknologi dilaksanakan oleh tiga orang koperator. Hasil } \\
\text { pengabdian menunjukkan bahwa cacing tanah Lumbricus rubellus mampu }\end{array}$} \\
\hline $\begin{array}{l}\text { Kata kunci } \\
\text { eksmecat } \\
\text { gelar teknologi, } \\
\text { kotoran sapi, } \\
\text { Lumbricus rubellus }\end{array}$ & \\
\hline
\end{tabular}


mengolah kotoran sapi dan limbah organik menjadi eksmecat 2,463 kali bobot badan per hari. Eksmecat yang dihasilkan rata-rata $2,463 \mathrm{~kg} / \mathrm{kotak}$ sarang dengan padat penebaran cacing tanah $25 \mathrm{~g} /$ kotak sarang dan lama budidaya 40 hari. Melalui penerapan gelar teknologi ini masyarakat pembudidaya cacing tanah dengan sisistem rak bertingkat tiga dapat memperoleh tambahan pendapatan Rp. 2.008.712,- bulan/are lahan budidaya. Simpulannya adalah pengolahan kotoran sapi dan limbah rumah tangga menjadi eksmecat dapat dilakukan menggunakan reaktor cacing tanah dengan sistem rak bertingkat dan dapat meningkatkan pendapatan masyarakat

Sitasi: Mashur, Agustin D.L.A., Ningtyas I.S.N., Multazam A., \& Ningsih M. (2020) Gelar Teknologi Pengolahan Kotoran Sapi dan Limbah Rumah Tangga Menjadi Eksmecat untuk Meningkatkan Pendapatan Masyarakat. Sasambo: Jurnal Abdimas (Journal of Community Service). 2(3), 86-94 DOI : $\underline{10.36312 / \text { sasambo.v2i3.279 }}$

\section{PENDAHULUAN}

Provinsi Nusa Tenggara Barat merupakan salah satu daerah sentra produksi sapi potong nasional untuk mensuplai kebutuhan bibit sapi dan ternak potong untuk lebih dari 12 provinsi di Indonesia. Populasi sapi di Provinsi Nusa Tenggara Barat (NTB) tahun 2018 tercatat sebanyak 1,183,570 ekor (591.785 satuan ternak) dengan rincian populasi ternak di Pulau Lombok 514,936 ekor dan di Pulau Sumbawa 668,634 ekor. Setiap ekor sapi dewasa (1 satuan ternak) menghasilkan kotoran ternak (feses) rata-rata sebanyak 23,59 kg/hari,sehingga produksi kotoran ternak sapi di NTB setiap tahun mencapai 13.960,21 ton/hari atau 5.025.674,93 ton/tahun. Limbah cair yang dihasilkan dari peternakan sapi potong 100-150 liter/ekor/tahun, sehingga produksi limbah cair dari peternakan sapi potong di NTB dapat mencapai 73.973.125 liter/hari atau 26.630.125.000 liter/tahun ((Dinas Peternakan dan Kesehatan Hewan Provinsi Nusa Tenggara Barat, 2020).

Potensi limbah padat dan cair dari peternakan sapi di NTB belum dimanfaatkan secara optimal. Introduksi teknologi pembuatan pupuk organik padat (kompos) dan pupuk organik cair (bio urin) dengan berbagai inovasi teknologi telah banyak diperkenalkan dan diterapkan kepada petani. Namun, belum diterapkan secara optimal, meluas dan terus menerus, terbukti masih banyak kotoran sapi yang dibiarkan menumpuk di sekitar kandang atau dialirkan ke sungai, saluran air/irigasi bahkan dibakar setelah kering. Apabila potensi kotoran sapi yang banyak ini tidak dikelola dengan baik maka akan menimbulkan masalah kebersihan dan kesehatan lingkungan, berupa timbulnya bau yang menyengat dan akan menjadi sumber penyakit bagi ternak dan manusia.

Permasalah tersebut membutuhkan inovasi teknologi antara lain 1) pengolahan kotoran ternak mengunakan reaktor cacing tanah Eisenia foetida dengan sistem rak bertingkat untuk menghasilkan pupuk organik padat eksmecat. Eksmecat dapat dimanfaatkan sebagai pupuk organik tanaman dan sebagai bahan pakan ikan. Mashur (2020a) telah menggunakan cacing tanah Eisenia foetida untuk mengolah kotoran sapi menjadi pupuk organik eksmecat karena cacing tanah Eisenia foetida memiliki habitat asli pada kotoran ternak (manure worm), sehingga menjadi solusi untuk mengolah kotoran sapi, dan 2) penggunaan rak bertingkat untuk efisiensi penggunaan lahan dalam rangka meningkatkan pendapatan masyarakat.

Cacing tanah Eisenia foetida dapat dijadikan sebagai reaktor untuk mengolah kotoran sapi menjadi eksmecat 1-2 kali bobot badannya per hari. Hal ini sesuai dengan hasil penelitian Mashur et al. (2001) menunjukkan bahwa cacing tanah Eisenia foetida merupakan salah satu jenis cacing tanah yang mempunyai keunggulan yang tinggi dalam reproduksi dan merombak bahan organik sebagai media atau pakannya bila dibandingkan dengan spesises lainnya. 
Kemampuan cacing tanah merombak bahan organik menjadi media atau pakannya dapat mencapai seberat bobot badannya selama 24 jam (Simandjuntan dan Waluyo, 2012). Haukka (2017) dapat mencapai dua kali bobot badannya per hari. Tingginya kemampuan cacing tanah dalam merombah bahan organik dan meredam bau busuk yang menyengat, sehingga cacing tanah juga dapat dimanfaatkan sebagai alternatif untuk mencegah pencemaran lingkungan, terutama yang ditimbulkan oleh limbah ternak, limbah pasar dan rumah tangga (Mashur at al., 2001).

Tujuan dari pengabdian masyarakat yang telah dilakukan adalah: (1) untuk mengetahui kemampuan cacing tanah Eisenia foetida dalam mengolah kotoran sapi menjadi eksmecat, yang diukur dari jumlah dan kualitas eksmecat yang dihasilkan; (2) untuk mengetahui tingkat pendapatan petani peternak yang menerapkan teknologi sistem rak bertingkat dan (3) memperkenalkan kepada masyarakat inovasi baru untuk mengolah kotoran sapi menjadi pupuk organik padat eksmecat.

\section{METODE PELAKSANAAN}

Pengabdian kepada masyarakat ini menggunakan metode Gelar Teknologi (Show Case Technology) dengan pertimbangan bahwa Gelar Teknologi adalah metode diseminasi teknologi baru yang paling efektif menurut pandangan petani (Mashur, 2015). Adapun alur penelitian yang dilakukan dengan metode ini adalah:

\section{Persiapan Kelompok Sasaran}

Mempersiapkan kelompok sasaran penerima manfaat dari gelar tekonologi pengolahan kotoran sapi dan limbah rumah tangga dengan reaktor cacing tanah Lumbricus rubellus menjadi eksmecat untuk meningkatkan pendapatan masyarakat. Kelompok sasarannya adalah milenial (pemuda dan pemudi) dan anggota kelompok kandang kolektif sapi potong Pade Angen di Dusun Montong Are Kelurahan Mandalika Kecamatan Sandubaya Kota Mataram. Jumlah milenial sebagai koperator (pelaksana) gelar teknologi tiga orang.

\section{Pembuatan Kandang Budidaya dan Rak Bertingkat}

Pembuatan kandang budidaya ukuran 4 meter x 6 meter x 3 meter. Pembuatan rak bertingkat tiga ukuran 1 meter x 2 meter x 3 meter. Semua biaya kandang budidaya dan rak bertingkat atas biaya swadaya masyarakat secara parisipatif.

\section{Fermentasi Bahan Media atau Pakan Cacing Tanah}

1. Fermentasi bahan media atau pakan cacing tanah yaitu campuran $50 \%$ kotoran sapi dan $50 \%$ limbah organik rumah tangga. Campuran media atau pakan ini merupakan campuran media atau pakan terbaik cacing tanah Eisenia foetida dalam menghasilkan kokon, biomassa dan eksmecat. Fermentasi bahan media atau pakan dilakukan secara aerob selama tiga minggu sesuai dengan hasil penelitian Mashur et al. (2001); Mashur, 2020a, 2020 b dan 2020c).

2. Setelah bahan media difermentasi selama tiga minggu, kemudian dikering anginkan dan dibalik-balik atau diaduk secara merata selama tiga hari untuk menghindari bau menyengat atau gas-gas yang timbul selama fermentasi yang akan menggangu kehidupan cacing tanah.

\section{Penyiapan Bibit dan Penebaran Cacing Tanah}

1. Penyiapan bibit cacing tanah Lumbricus rubellus dewasa yang ditandai dengan adanya "klitelum" (gelang warna putih) pada bagian depan cacing tanah.

2. Cacing tanah yang digunakan sebanyak 25 gram/kotak sarang. Jumlah kotak sarang yang digunakan sebanyak 72 buah kotak sarang, sehingga kebutuhan bibit cacing tanah sekitar 1.800 gram 
3. Setelah bahan media atau pakan selesai difermentasi dan dikering anginkan selanjutnya dilakukan penebaran cacing tanah dengan memasukkan cacing tanah ke dalam kotak sarang yang telah diberikan media sebanyak dua kilogram untuk 40 hari budidaya dengan padat penebaran 25 gram/kotak sarang.

4. Cacing tanah yang ditebar seberat 25 gram/kotak sarang juga dihitung jumlahnya, karena biomassa cacing tanah selain ditimbang bobotnya (gram) juga dihitung jumlahnya (ekor)

5. Kotak-kotak sarang yang telah ditebar cacing tanah ditempatkan sesuai perlakuan pada masing-masing tingkatan rak (tingkat 1, 2 dan 3). Setiap tingkat rak terdapat 24 kotak sarang.

\section{Pemberian Pakan dan Panen Eksmecat}

1. Pemberian media atau pakan cacing tanah tambahan berupa campuran $50 \%$ kotoran sapi dan 50\% limbah organik rumah tangga dilakukan setiap tiga hari sekali dengan berat dua kali bobot badan cacing tanah. Pakan ditebar pada permukaan media sebelumnya sebanyak 150 gram (75 gram feses sapi dan 75 gram limbah organik rumah tangga

2. Setelah 40 hari budidaya dilakukan panen pada hari ke 41 dengan melakukan panen kokon/telur, panen biomassa cacing tanah dan panen eksmecat cacing tanah yang dihasilkan.

3. Produksi eksmecat diukur berdasarkan berat eksmecat yang dihasilkan berupa sisa media atau pakan cacing tanah. Kualitas eksmecat diukur berdasarkan hasil analisis laboratorium tanah untuk unsur-unsur hara makro $(\mathrm{N}, \mathrm{P}, \mathrm{K}$, kandungan bahan organik eksmecat dan $\mathrm{C} / \mathrm{N}$ ratio pada Laboratorium Tanah Balai Pengkajian Teknologi Pertanian Nusa Tenggara Barat di Narmada. Analisis kandungan nutrisi eksmecat dilakukan di laboratorium nutrsi dan pakan Fakultas Peternakan Universitas Mataram secara proksimat.

\section{Menghitung Pendapatan Masyarakat Pembudidaya Cacing Tanah}

Menghitung pendapatan masyarakat pengolah kotoran sapi dan limbah organik rumah tangga menjadi eksmecat dengan sistem rak bertingkat tiga pada skala usaha 100 meter $^{2}$ dengan analisis input output.

\section{HASIL DAN PEMBAHASAN}

Eksmecat (eksreta media cacing tanah) merupakan sisa media atau pakan cacing tanah yang berasal dari berbagai limbah organik telah bercampur dengan ekstreta (sisa hasil pencernaan cacing tanah), cacing tanah yang mati selama budidaya, sisa kokon (telur cacing tanah yang tidak menetas). Istilah eksmecat diperkenal pertama kali sebagai hasil penelitian Mashur et al. (2001). Istilah lain yang digunakan untuk eksmecat adalah kascing (bekas cacing) atau vermikompos (kompos dari cacing tanah). Eksmecat merupakan pupuk organik padat yang dihasilkan dari budidaya cacing tanah dengan menggunakan berbagai jenis bahan organik menjadi media atau pakan cacing tanah. Eksmecat mengandung unsur-unsur hara makro dan mikro serta hormone tumbuh sehingga bermanfaat bagi tanaman. Akhir-akhir ini eksmecat telah digunakan oleh peternak ikan menjadi pakan ikan. Mashur (2020c) memperkenal pellet eksmecat sebagai pakan ikan alternatif di Era New Normal Covid-19. Dengan demikian, eksmecat dapat memberikan nilai tambah dalam rangka meningkatkan pendapatan petani atau peternak pembudidaya ikan. Pada kegiatan pengabdian masyarakat ini melalui gelar teknologi pengolahan kotoran sapi dengan reaktor cacing tanah Lumbricus rubellus menjadi eksmecat untuk meningkatkan pendapatan petani peternak, akan dibahas produksi dan kualitas eksmecat yang dihasilkan serta keuntungan yang diperoleh petani 
peternak pembudidaya dalam menerapakan inovasi budidaya cacing tanah dengan sistem rak bertingkat.

\section{Produksi Eksmecat}

Produksi eksmecat diperoleh dengan cara menimbang sisa media setelah panen cacing tanah. Jumlah eksmecat yang dihasilkan pada setiap tingkatan rak bertingkat disajikan pada Tabel 1.

Tabel 1. Produksi eksmecat pada masing-masing tingkat rak

\begin{tabular}{llll}
\hline \multicolumn{4}{c}{ Rata-rata produksi eksmecat per kotak sarang $(\mathrm{kg})$} \\
\hline No. Kotak Sarang & Rak Tingkat 1 & Rak Tingkat 2 & Rak tingkat 3 \\
\hline 1 & 3.4 & 2.0 & 1,9 \\
2 & 4,1 & 1,8 & 1,9 \\
3 & 3,5 & 2,0 & 1,9 \\
4 & 4,0 & 2,1 & 2,0 \\
5 & 3,6 & 1,8 & 1,9 \\
6 & 3,4 & 2,0 & 1,9 \\
7 & 3,5 & 2,0 & 1,8 \\
8 & 3,2 & 2,0 & 1.9 \\
9 & 1,6 & 3,5 & 1,6 \\
10 & 2,0 & 3,2 & 3,3 \\
11 & 2,0 & 3,3 & 1,4 \\
12 & 2,0 & 3,7 & 3,7 \\
13 & 1,8 & 3,4 & 1,6 \\
14 & 2,0 & 3,7 & 1,5 \\
15 & 2,0 & 3,0 & 2,9 \\
16 & 1,8 & 3,3 & 3,1 \\
17 & 2,4 & 2,1 & 1,5 \\
19 & 2,4 & 2,6 & 3,3 \\
20 & 2,0 & 2,2 & 3.3 \\
21 & 2,4 & 2,1 & 3,2 \\
22 & 2,5 & 2,6 & 3,2 \\
23 & 2,6 & 2,3 & 3.1 \\
24 & 2,5 & 2,4 & 3,1 \\
25 & 2,4 & 2,5 & 2,9 \\
\hline Rata-rata & 2.29 & 2,567 & \\
\hline
\end{tabular}

Data pada Tabel 1 menunjukkan bahwa produksi eksmecat pada rak tingkat 1 rata-rata 2,629 kg/kotak sarang, pada rak tingkat 2 rata-rata 2,567 kg/kotak sarang dan pada rak tingkat 3 rata-rat $2,192 \mathrm{~kg} / \mathrm{kotak}$ sarang. Berdasarkan data tersebut diperoleh produksi eksmecat dari tiga tingkat rak rata-rata $2,463 \mathrm{~kg} / \mathrm{kotak}$ sarang, seperti ditampilkan pada Gambar 1.

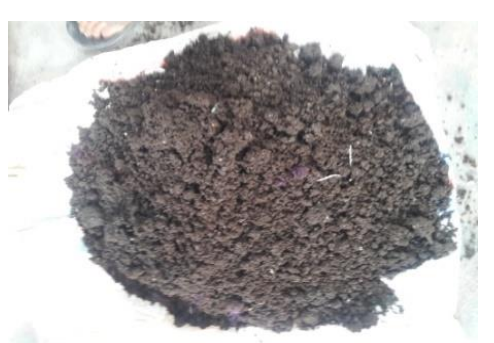

Gambar 1. Eksmecat yang dihasilkan dari campuran 50\% kotoran sapi dan $50 \%$ limbah organik rumah tangga 
Hal ini berarti bahwa kemampuan cacing tanah Lumbricus rubellus dalam memproduksi eksmecat 2,463 kali bobot badannya per hari. Hasil penelitian ini lebih tinggi dari hasil penelitian Simandjuntan dan Waluyo (2012) satu kali bobot badan selama 24 jam; Haukka (2017) dua kali bobot badan per hari dan Mashur et al. (2001). Dengan demikian, cacing tanah Lumbricus rubellus dapat digunakan sebagai pengolah kotoran sapi dan limbah rumah tangga menjadi eksmecat dengan kemampuan yang sangat tinggi (Roslim et al., 2013; Putra et al., 2018).

Berdasarkan data pada Tabel 1 nampak bahwa terdapat perbedaan kemampuan cacing tanah dalam mengolahan limbah organik menjadi eksmecat berdasarkan tingkatan rak. Ada kecenderungan bahwa semakin tinggi tingkatan rak maka semakin kecil kemampuan cacing tanah mengolah limbah organik menjadi eksmecat. Hal ini disebabkan karena semakin tinggi tingkatan rak semakin panas udara akibat dari atap kandang dari seng, di mana produksi eksmecat rak tingkat $1>$ rak tingkat $2>$ rak tingkat 3 . Hal ini sesuai dengan dengan hasil penelitian Mashur (2020a) bahwa suhu merupakan salah satu faktor lingkungan yang berpengaruh terhadap produksi kokon dan reproduksi cacing tanah yang akan berpengaruh terhadap produksi biomassa dan eksmecat. Suhu yang terlalu rendah atau terlalu tinggi akan mempengaruhi proses biologis seperti pernafasan, perkembangbiakan dan metabolisme cacing tanah (Simandjuntak dan Waluyo, 2012). Temperatur optimum untuk pertumbuhan cacing tanah Eisenia foetida adalah $25^{\circ} \mathrm{C}$ (Minnich, 2017). Hasil penelitian ini menunjukkan suhu rata-rata media $27^{\circ} \mathrm{C}$ dan suhu udara di dalam kandang dapat mencapai $28-30^{\circ} \mathrm{C}$.

\section{Kualitas Eksmecat}

Parameter yang digunakan untuk mengukur kualitas eksmecat adalah unsur-unsur hara makro $(\mathrm{N}, \mathrm{P}, \mathrm{K})$, kandungan bahan organik dan $\mathrm{C} / \mathrm{N}$ ratio, sedangkan parameter lain seperti unsur hara mikro, hormone tumbuh dan enzim yang dikandungnya belum dapat dilakukan karena keterbatasan waktu dan biaya penelitian. Kualitas eksmecat yang dihasil dari kegiatan pengabdian ini seperti ditampilkan ada Tabel 2.

Tabel 2 Kualitas ekmecat yang dihasilkan dari gelar teknologi pengolahan kotoran sapi dengan reaktor cacing tanah Lumbricus rubellus

\begin{tabular}{llllllll}
\hline No & Jenis eksmecat & \multicolumn{6}{c}{ Kandungan unsur-unsur hara eksmecat (\%) } \\
\cline { 3 - 8 } & & $\mathrm{N}$ & $\mathrm{P}$ & $\mathrm{K}$ & $\mathrm{C}$ organik & Bahan organik & C/NRatio \\
\hline 1 & Feses sapi*) & 1,7 & 0,49 & 1,11 & 26,68 & 45,89 & 15,69 \\
2 & $\begin{array}{l}\text { Limbah organik } \\
\text { rumah tangga **) }\end{array}$ & 3,38 & 0,48 & 1.79 & 46,27 & 79,59 & 13,69 \\
& $\begin{array}{l}\text { Campuran 50\% } \\
\text { kotoran sapi + 50\% } \\
\text { limbah organik }\end{array}$ & 2,20 & 0,53 & 1,32 & 33,13 & 57,05 & 15,06 \\
& & & & & & \\
rumah tangga & & & & & & \\
\hline
\end{tabular}

Sumber:*) Mashur (2020b); **) Mashur (2020c)

Berdasarkan hasil penelitian pada Tabel 2 menujukan bahwa kualitas eksmecat yang dihasil dari kegiatan pengabdian ini cukup baik dari segi kandungan unsur-unsur hara makro, bahan organi dan $\mathrm{C} / \mathrm{N}$ ratio jika dibandingkan dengan kompos feses sapi tanpa menggunakan reaktor cacing tanah Eisenia foetida (Saputro et al., 2014) atau eksmecat feses sapi (Mashur, 2020b) atau eksmecat limbah organik rumah tangga (Mashur, 2020c). Casting atau eksmecat yang kaya unsur hara esensial seperti C, N, P dan K sangat dibutuhkan tanaman untuk pertumbuhannya (Minnich, 2017).

Gaddie dan Douglas (2017) menyatakan bahwa kandungan unsur hara casting atau eksmecat bergantung pada spesies cacing tanah yang digunakan, bahan pakan dan umur 
casting atau eksmecat sejak dihasilkan. Pada umum casting atau eksmecat mengandung $\mathrm{N}=0,50-2,00 \% ; \mathrm{P}=0,60-0,68 \%$ dan $\mathrm{K}=0,10-1,10 \%$. Kandungan $\mathrm{N}$ casting atau eksmecat berasal dari perombakan bahan organik media yang kaya Nitrogen dan ekskresi mikroba yang bercampur dengan media dalam sistem pencernaan cacing tanah (Tiwari et al., 2019). Peningkatan kandungan nitrogen dalam casting atau eksmecat selain dipengaruhi oleh adanya proses mineralisasi bahan organik dari cacing tanah yang telah mati, juga oleh urin yang dihasilkan dan eksresi mucus dari tubuh cacing tanah yang kaya nitrogen (Gaddie dan Douglas, 2017). Hal ini sesuai dengan hasil penelitian Businelli et al. (2014) casting atau eksmecat terdiri dari dua bagian yaitu padat dan cair. Nitrogen dalam casting atau eksmecat pada umumnya berada dalam dua bentuk yaitu residual protein dan protein yang disentesis oleh sel-sel bakteri yang berada dalam bentuk tersedia bagi tanaman.

\section{Pendapatan masyarakat pembudidaya cacing tanah dengan sistem rak bertingkat}

Berdasarkan hasil penelitian pada Tabel 1 dapat dihitung produksi eksmecat dengan sistem rak bertingkat tiga, yaitu: rak 3 tingkat x 24 kotak sarang/tingkat x 2,463 kg/kotak sarang= $177,336 \mathrm{~kg}$ eksmecat selama 40 hari untuk satu periode pengolahan pada rak bertingkat ukuran 1 meter x 3 meter x 2 meter (Gambar 2). Apabila frekuensi pengolahan kotoran sapi dan limbah rumah tangga dilakukan sembilan kali per tahun $(9$ kali $\times 40$ hari/periode pengolahan $=360$ hari) maka produksi eksmecat yang dihasil sebanyak $9 \mathrm{x}$ $177,336 \mathrm{~kg}=1.596,024 \mathrm{~kg}$ eksmecat/tahun/rak bertingkat tiga. Apabila lahan yang digunakan untuk mengolah kotoran sapi dan limbah organik rumah tangga seluas $100 \mathrm{~m}^{2}$ (satu are) maka jumlah rak bertingkat yang dapat ditampung sebanyak 33,3 buah rak bertingkat tiga (100 $\left.\mathrm{m}^{2} / 3 \mathrm{~m}^{2}=33,3\right)$.

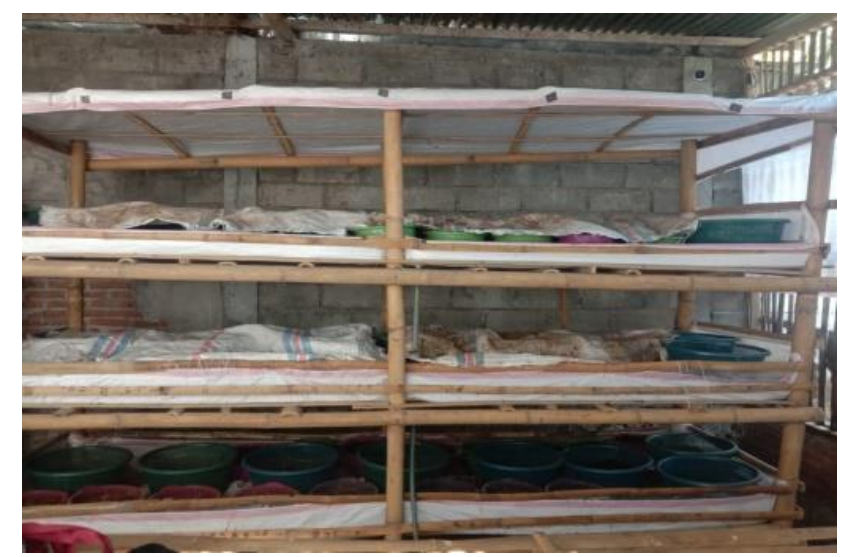

Gambar 2. Pengolahan kotoran sapi dan limbah organik rumah tangga menjadi eksmecat dengan teknologi sistem rak bertingkat

Dengan memperhitungkan jarak setiap rak bertingkat untuk mempermudah pengelolaanya maka diambil 50\% dari daya tampung luas kandang $100 \mathrm{~m}^{2}$, yaitu 15 buah rak bertingkat tiga. Jumlah produksi eksmecat yang dihasilkan pada lahan kandang seluas $100 \mathrm{~m}^{2}$ sebanyak 15 x 1.596,024 kg eksmecat/tahun $=23.940,36 \mathrm{~kg}$ eksmecat/tahun. Harga eksmecat di pasaran saat ini rata-rata $\mathrm{Rp} .1500 / \mathrm{kg}$ maka tambahan penghasilan masyarakat pembudidaya cacing tanah atau pengolah kotoran sapi dan rumah tangga sebesar Rp.35.910,540/tahun. Dengan perhitungan biaya operasional pengolahan kotoran sapi dan limbah rumah tangga menjadi pupuk organik padat eksmecat Rp.1.800.000/tahun; biaya penyusutan kandang budidaya Rp.1.000.000/tahun,; biaya penyusutan rak bertingkat Rp.1.500.000,/tahun- bibit cacing tanah Rp.7.290.000/tahun dan kotak sarang Rp.216.000 maka seluruh biaya produksi sebesar Rp.11.806.000,. Dengan demikian, pendapatan yang diperoleh masyarakat pembudidaya cacing tanah pengolah kotoran sapi dan limbah organik rumah tangga menjadi eksmecat sebesar Rp.24.104.500/tahun atau Rp.2.008.712,-/bulan. 
Hasil perhitungan ini lebih rendah dari hasil penelitian Mashur et al. (2001) sebesar Rp.31.292.556/tahun atau Rp.2.607,713/bulan karena memperhitungkan tambahan pendapatan bersumber dari penjualan produksi kokon dan biomassa.

\section{KESIMPULAN}

Gelar teknologi merupakan salah satu metode diseminasi teknologi pengolahan kotoran sapi dan limbah rumah tangga menjadi eksmecat dalam rangka meningkatkan pendapatan masyarakat dengan menggunakan reaktor cacing tanah Lumbricus rubellus. Cacing tanah Lumbricus rubellus mampu mengolah campuran 50\% kotoran sapi dan 50\% limbah organik rumah tangga menjadi pupuk organik padat eksmecat 2,463 kali bobot badannya per hari. Pendapatan masyarakat pembudidaya cacing tanah dapat meningkat sebesar Rp.2.008.712/bulan dengan menggunakan teknologi rak bertingkat pada skala usaha 100 meter $^{2}$

\section{SARAN}

Untuk menentukan kualitas eksmecat dari parameter unsur-unsur hara mikro, hormone tumbuh, enzim dan bakteri perombak bahan organik serta parameter lainnya disarankan untuk dilakukan penelitian lain di masa yang akan datang termasuk penelitian kandungan nutrisi dari eksmecat sebagai bahan pakan ikan dan ternak.

\section{UCAPAN TERIMA KASIH}

Ucapan terima kasih disampaikan kepada Ketua Yayasan IKIP Mataram, Rektor Undikma dan Kepala LPPM Undikma yang telah memberikan dana pengabdian kepada masyarakat internal Undikma tahun 2020. Ucapan terima kasih juga disampikan kepada tim peneliti, ketua kelompok tani ternak kandang kolektif Pade Angen Dusun Montong Are Kelurahan Mandalika Kecamatan Sandubaya Kota Mataram dan mahasiswa Fakultas Kedokteran Hewan Undikma yang telah bergabung dalam penelitian ini dan membantu dalam pelaksanaan penelitian dan pengabdian kepada masyarakat sehingga berjalan dengan baik

\section{DAFTAR PUSTAKA}

Businelli, M., P. Perucci, M. Patumi and B.L. Gins Quiani. (2014). Chemical composition and enzymic activity of some worm cast. Plant and Soil. 80(5):417-422

Dinas Peternakan dan Kesehatan Hewan Provinsi Nusa Tenggara Barat. (2020). Laporan Tahunan Dinas Peternakan dan Kesehatan Hewan Propvinsi Nusa Tenggara Barat. Tahun 2019. Mataram

Gaddie, R.E \& D.E. Douglas. (2015). Earthworm for Ecology and Profit. Bookworm Publishing Campany. Vol.1. Ontario California.

Haukka, J.K. (2017). Growth and Survival of Eisenia foetida (Sav.) (Oligochaeta: Lumbricidae) in relation to temperature, moisture and presence of Enhytracus albidus (Henle) (Enchytraidae), Biol. Fertil. Soil. 3 :99-102. https://researchportal.helsinki.fi/en/publications/growth-and-survival-of-eiseniafoetida-sav-oligochaeta-lumbricida

Mashur, G. Djajakirana, Muladno \& D.T.H. Sihombing. (2001). Kajian Perbaikan Teknologi Budidaya Cacing Tanah Eisenia foetida Savigny Untuk Meningkatkan Produksi Biomassa dan Kualitas Eksmecat dengan Memanfaatkan Limbah Organik. Media Peternakan Journal of Animal Sciece and Technology, 24 (1), 28-38. http://journal.ipb.ac.id/index.php/mediapeternakan /article/view/11652

Mashur. (2015). Peranan Kelembagaan Penyuluhan Dalam Mempercepat Diseminasi Teknologi Hasil Penelitian HHBK. Jurnal pbthhbk.litbang.dephut.go.id. 1 (1):555-562 
Mashur. (2020a). Pemanfaatan Sampah Pasar Sebagai Media Budidaya Cacing Tanah Eisenia fetida Untuk Meningkatkan Kokon dan Biomassa. Geodika: Jurnal Kajian Ilmu dan Pendidikan Geografi. 4(1): 75-84. http://ejournal.hamzanwadi.ac.id/index.php/gdk/article/view/2066 ..(2020b). Produksi Kokon dan Biomassa Cacing Tanah Eisenia foetida Pada Berbagai Media Budidaya Limbah Peternakan. Bioscientist: Jurnal Ilmiah Biologi 8 (1): 48-57. http://ojs.ikipmataram.ac.id/index.php/bioscientist/article/view/2608 ..(2020c). Pemanfaatan Sampah Organik Rumah Tangga Sebagai Media Budidaya Untuk Meningkatkan Produktivitas Cacing Tanah Eisenia foetida. Jurnal Sangkareang Mataram. 6(2): 6-1. https://www.google.com/search?q=2020c).+Pemanfaatan+Sampah+Organik+Rumah+T angga+Sebagai+Media+Budidaya+Untuk+Meningkatkan+Produktivitas+Cacing+Tana $\mathrm{h}+$ Eisenia+foetida.+Jurnal+Sangkareang+Mataram.+

Minnich, J. (2017). The Earthworms Book. Rodale Press Emmaus. P.A. USA

Putra, S. E., Johan, I., \& Hasby, M. (2018). Pengaruh pencampuran kotoran ternak sebagai media kultur terhadap pertambahan populasi cacing tanah (Lumbricus Rubellus). Jurnal Dinamika Pertanian. $34 \quad$ (1): https://scholar.google.co.id/citations?user=OFZEqCMAAAAJ\&hl=en

Roslim, D. I., Nastiti, D. S. \& Herman. (2013). Karakter Morfologi dan Pertumbuhan Tiga Jenis Cacing Tanah Lokal Pekan Baru pada Dua Macam Media Pertumbuhan. Jurnal Biosantifika. Jurusan Biologi Fakultas Matematika dan Ilmu Pengetahuan Alam. Universitas Riau. Indonesia. https://journal.unnes.ac.id/nju/index.php/biosaintifika/article/view/2567

Saputro, D.W., B. R., Wijaya dan Y., Wijayanti. (2014). Pengelolaan Limbah Peternakan Sapi Untuk Meningkatkan Kapasitas Produksi Pada Kelompok Ternak Patra Sutera. $\begin{array}{llllll}\text { Jurnal } & \text { Rekayasa. } & 12 & \text { (2) } & \text { 91-98. }\end{array}$ https://journal.unnes.ac.id/nju/index.php/rekayasa/article/view/10124/0

Simandjuntak, A.K. \& D. Waluyo. (2012). Cacing Tanah. Budidaya dan Pemanfaatannya. PT. Penebar Swadaya. Jakarta

Tiwari, S.C., B.K. Tiwari, and R.R. Mishra. (2019). Microbial population enzyme activities and nitrogen phosphorus-potassium enrichment in earthworm cast and in the surrounding soil of a pineapple plantation. Biol. Fertil. Soils. 8:178-182. https://www.researchgate.net/publication/227000366_Microbial_populations_enzyme_ activities_and_nitrogen-phosphorus-potassium_ 